\title{
DIRECTIONS OF DEVELOPMENT OF DIGITAL SOCIETY IN UKRAINE
}

\author{
Oksana Sokolovska'
}

\begin{abstract}
The purpose of the work is to identify the problems and directions of digital society's development in Ukraine. The current stage of the information society has been investigated by the author. Under the influence of development of new technologies, it has clear signs of a transition to a digital society. It has been proven in the article that the widespread use of mobile devices in the life of social individuals alters the interaction between public authorities and stakeholders dramatically. The methodological basis of the research consist of the studying the state of transition of the information society to the digital one using logical analysis, synthesis and comparison, as well as conducting an expert survey by the Delphi method. Results of the research showed important problems and directions for further work on the development of digital economy and digital society in the region, such as: the level of access to the high-speed Internet in rural areas is far behind urban indices; along with the great desire of population to develop the e-democracy, there is a problem of improper work of relevant digital resources; e-Government is developing actively in terms of technology and software, but its efficiency is still very low. It has been argued in the article that not all administrative processes and procedures can be automized during the digital transformation. It has been shown by the authors that the positive example of the development of digital society's foundations at the regional and local level is becoming a factor for the digitalization of all public administration bodies of Ukraine. The results of an expert survey on assessing the digital development of Dnipropetrovsk region has been presented in the article. In Ukraine's realities, the introduction of digital technologies, including the artificial intelligence, is a benchmark for the Government's strategic goals in the long-term future. Positive experience of digital society's development at the regional and local levels can be a driving force for the advancement of digital deployments at the national level. To that end, the evaluation of the electronic readiness of districts, cities and united territorial communities has been made in Dnipropetrovsk region of Ukraine.
\end{abstract}

Key words: digital technology, artificial intelligence, administrative processes, electronic governance, electronic democracy.

JEL Classification: O14, D73, 016

\section{Introduction}

The research methodology is aimed at studying the state of transition of the information society to the digital one using logical analysis, synthesis and comparison, as well as conducting an expert survey by the Delphi method. The scientific originality of the article is that the factors of the transition of the information society to the digital one, which can be used both at the regional and local levels, have been identified.

The practical significance of the article is that the peculiarities of digital society's development in one of the industrialized regions of Ukraine have been identified based on the study of territorial communities' e-readiness. The result of the study is the identification of the main priorities for the development of digital society in Dnipropetrovsk region of Ukraine.

The aim of the article is to identify the problems and directions of digital society's development in Ukraine.

\section{Transition from the information society to the digital society}

Many authors give different interpretations of the concept of the «information society», but what they all have in common is that such a society is based on information and communication links.

Corresponding author:

${ }^{1}$ Dnipropetrovsk Regional Institute for Public Administration

of the National Academy for Public Administration under the President of Ukraine, Ukraine.

E-mail: anaskosok@ukr.net

ORCID: https://orcid.org/0000-0002-3367-0276 
By the encyclopedic definition, the «information society» is «a community in which information and communication technologies are central to social and economic activity» (Dutton, 2003). A more specific wording is that $\ll$ the information society is a neo-manufacturing society in which information is both the raw material we produce and manipulate, and the finished good we consume» (Floridi, 2014).

The initial milestones of the information society date back to the days when writing, printing and then media were invented. The final formation of the information society occurred when the development of information and communication technologies (hereinafter - ICT) enabled the processing of information through means of transmission and recording (Floridi, 2014). In the pursuit of the rapid spread and adoption of ICT, it is necessary to understand that one of its important aspects is the adaptation of humans to technology (Kvitka, 2020).

On the other hand, further large-scale development of ICT influenced on a society. This impact needs the ethical and intellectual basis of ICT's use to be understood and justified (Floridi, 2014). In this sphere, scientists assume the interconnection of digital and physical worlds, that is, they make researches, which show that the human perception of the technology world can determine human's possible future activities (Dufva \& Dufva, 2019).

The use of information and communication technologies transformed the society of a particular country into an information society (Koval, Zamlynskyi, Kolomiiets, 2018). Moreover, public administration was made with the help of ICT and the public and became, in fact, the e-government (Floridi, 2014). That is, the e-government became the ground for the future introduction of the latest technologies. And it is the digital transformation that leans on this previous experience.

Digital ICTs are making closer the overcoming of the digital divide between territories and are tied to big data, social networks, the e-voting, information and cybersecurity, blockchain, the Internet of Things and more. The significant for these digital technologies is the use of the technology of the artificial intelligence (Kvitka et al., 2020).

Studying the development of technologies in the evolutional context, digital ICTs are transforming the information society into a digital community (Floridi, 2014). From now on, each of us feels that digital technology entered the everyday life of the most of individuals. Modern cell phones, information networks and other things, which were only predicted by authors in science fiction books several decades ago, are a reality today (Dufva \& Dufva, 2019). In our deep conviction, the beginning of the transformation from the information society to the digital one started with the launch of Apple's phones, namely Iphone. The concept of the mobile phone of such type changed the possibilities of digital technologies' use radically. The smartphone opened the opportunity to work without being tied to its owner's location, by accessing 3G/4G broadband mobile Internet.

An example of the interest of the population to smartphones and digital technologies is the growing number of Internet users worldwide. For example, according to Eurostat, in the European Union countries the amount of people aged 16 to 74 who frequently use the Internet (daily or almost daily on average) accounted for $38 \%$ of their total in 2007, and for $76 \%$ in 2018. Moreover, statistics considered the use of the Internet network, which includes all places and ways of access for private or work purposes (Eurostat, 2018).

For comparison with the Ukrainian realities of Internet penetration in Ukraine, the number of Internet users increased by $59 \%$ for almost 15 years, from $12 \%$ (in 2004) to $71 \%$ (in third quarter of 2019). The rate of Internet access in villages and small towns is increasing gradually, coming closer to the regional cities. The big growth over the last three years happened as for the vast majority of users who have connected to the Internet in 2019, the smartphone is the first and only one mobile device to access the network. $22 \%$ of users access the Internet exclusively through their smartphones. Most of the population under 35 are Internet users (Factum Group Ukraine, 2019). Thus, population's «smarting» contributes slowly to the digital transformation of citizens.

During recent years, the gradual transition from the information society to the digital one has become more tangible (Kvitka et al., 2019). In Ukraine, at the state level, a number of defining regulatory documents were adopted, namely concepts: the development of the e-governance, the development of the e-democracy, as well as the development of the digital economy and society (Yankovyi et al., 2019). Therefore, it should be noted that the state is trying to act systematically in the studying and implementation of the latest 
digital technologies in public administration (including local governments).

It should be noted also that there is a digital transformation in the public administration, which aims to change the organizational and bureaucratic aspects of the activity, taking into account interests of the stakeholders - business and citizens. The speed of the digital transformation will depend on many factors. At the same time, the use of the latest technologies by the stakeholders will require promptness in the activity of the authorities. This, in turn, will lead to the adaptation of administrative processes for the provision of services to external needs. In these circumstances, stakeholders play not only a role of a customer, but become a partner in transformation via the use of the latest technologies in service delivery. In this context, scholars interpret «digital transformation is a holistic effort to revise core processes and government services beyond the traditional digitization efforts» (Mergel, Edelmann \& Haug, 2019). Considering the human factor, it can be assumed that digital transformation in public authorities will be slower than expected.

In general, the automation of processes in public administration is an attractive field for the introduction of digital technologies, in particular the artificial intelligence technology. In some cases, optimism in the implementation of the artificial intelligence in public administration is faced with the impossibility of automating of administrative processes and procedures from a technical point of view. That's why the question to outline the capabilities of such automation, as «from the multitude of thousands of administrative procedures, decision makers must select those processes that are appropriate for partial or full automation», arises (Etscheid, 2019). We believe that the implementation of the artificial intelligence in public administration will require changes in existing administrative models of the organization, somewhere without the human staff in automatic mode.

Artificial intelligence is a technology that allows computer systems to fulfill tasks, close to the level of the human intelligence. The availability of data, analytics and cloud computing has a positive impact on the development of the artificial intelligence technology. This accessibility is an opportunity for the machine learning and the development of algorithms for this technology (UN E-Government Survey 2018).

We believe that the artificial intelligence, being a major factor in the digital society, should a priori be taken into account when designing and implementing digital ICT in public administration.

Public administration resources should be directed to the fulfillment of one of the main tasks - the provision of qualitative administrative services. That is why, the technology of the artificial intelligence is designed to effectively allocate resources in public administration's bodies, the operation of software bots for the provision of certain administrative services, the automation of decision making on minor everyday issues, responding to templates of citizens, adjusting flexibility in responding to emergencies, forecasting changes in environments, traffic management, and also in recognition and translation of different languages (UN E-Government Survey 2018).

In Ukraine's realities, the introduction of digital technologies, including the artificial intelligence, is a benchmark for the Government's strategic goals in the long-term future. But with all positive intentions, this situation needs to stimulate the development. The necessity to solve all existing issues related to technical support and shortage of the specialist staff does not hasten the adoption of digital technologies in public administration. Positive experience of digital society's development at the regional and local levels can be a driving force for the advancement of digital deployments at the national level. To that end, the evaluation of the electronic readiness of districts, cities and united territorial communities has been made in Dnipropetrovsk region of Ukraine.

\section{Perspectives of digital society's development in Dnipropetrovsk region of Ukraine}

The determination of perspectives of digital society's development in Dnipropetrovsk region was conducted by the remote method under the creation of the regional program «Electronic Dnipropetrovsk region» for 2020-2022 and engaged an expert survey of 554 persons who included the authorities, business, science and the public.

The Delphi survey questionnaire was designed on the basis of the results of a preliminary analysis of the condition of «informatization» in the region. The experts were asked to answer questions about the level of development of the digital society of Dnipropetrovsk region by the following estimates: 1 - not important / incredibly / very low; 2 - little important / little likely / low; 3 - important to some extent / probably to some extent / medium; 
4 - important / probably / high level;

5 - very important / very likely / very high level;

0 - difficult to answer.

The research results given below made it possible to include significant aspects of public administration digitization to Dnipropetrovsk Region Electronic Informatization Program for 2020-2022 (Dnipropetrovsk Region Council, 2019). In fact, the draft program of Dnipropetrovsk Regional Council, which was approved in October 2019 , is a roadmap for the implementation of the idea of digital society in the region in accordance with world standards, which takes into account the interaction of government, business and civil society institutions (Baklanova, Petrova, Koval, 2020).

The following digital development indices defined by the International Telecommunication Union and other specialized UN units were taken as the basis of the research:

- ICT development index (2017) - Internet access, digital inequality issues;

- E-Government Development Index (2018) Information and Communication Structure and Document Management;

- E-Participation Index (2018).

The research allowed to suggest a number of conclusions regarding the digital development of one of the most industrial regions of Ukraine (Electronic Dnipropetrovsk region 2020-2022, 2019). The peculiarity of the research was that there were more than $29 \%$ of business representatives and $30 \%$ of representatives of civil society institutions among the experts. Other experts were representatives of public authorities and budgetary institutions. This provided a qualitative presentation of different opinions and, accordingly, a synergistic effect of the cross-sectoral interaction.
According to data of Table 1 by experts' opinions, the level of Internet access in Dnipropetrovsk region is at a rather low level, although it is a bit higher than the index of the International Telecommunication Union for the whole country. At the same time, the level of the information security is poor. One can even say that cyber threats are an urgent problem in Ukraine. The same applies to assessing the level of the digital piracy. Too high figures indicate a clear shortcoming on the part of the authorities to end such criminal practice.

The level of the e-democracy in any country is linked closely to the characteristics of traditional democracy and, above all, to the peculiarities of the rule of law and civil society. Taking into account the development of these two factors, Ukraine occupies a very middle place in the world ranking (Table 2). These is reflected also by the results of the research. At the same time, it is necessary to mention the great demand and willingness for the e-democracy from the population.

E-Government in Ukraine is developing actively during the last 4 years. It happened mostly thank to international grants. Meanwhile, in 2 years from 2016 to 2018, Ukraine's international rating dropped by 20 points. No clear explanation for this situation has been given yet. According to all expectations of specialists, counting the high volume of advancement of digital technologies, it should be the opposite. Perhaps this is somehow correlated with the general assessment of country's public authority corruption and influences directly the attitude to the e-government.

The results of this study have rather raised a number of questions, which need further research, than gave a clear vision of ways to solve the described problems (Table 3).

Table 1

\section{Level of development of information and communication infrastructure}

\begin{tabular}{|l|c|c|c|c|c|c|c|}
\hline \multirow{2}{*}{ Quality of the Internet access } & Score & 0 & 1 & 2 & 3 & 4 & 5 \\
\cline { 2 - 7 } & Survey data & $0.6 \%$ & $0.6 \%$ & $4.5 \%$ & $21.2 \%$ & $35.8 \%$ & $37.4 \%$ \\
\hline \multirow{2}{*}{$\begin{array}{l}\text { Quality of Internet-providers } \\
\text { services }\end{array}$} & Score & 0 & 1 & 2 & 3 & 4 & 5 \\
\cline { 2 - 8 } & Survey data & $0.0 \%$ & $1.7 \%$ & $6.2 \%$ & $31.3 \%$ & $43.6 \%$ & $17.3 \%$ \\
\hline \multirow{2}{*}{$\begin{array}{l}\text { Quality of 3G/4G mobile internet } \\
\text { services }\end{array}$} & Score & 0 & 1 & 2 & 3 & 4 & 5 \\
\cline { 2 - 8 } & Survey data & $2.2 \%$ & $1.7 \%$ & $8.4 \%$ & $38.0 \%$ & $36.3 \%$ & $13.4 \%$ \\
\hline \multirow{2}{*}{$\begin{array}{l}\text { Degree of informational systems } \\
\text { protections }\end{array}$} & Score & 0 & 1 & 2 & 3 & 4 & 5 \\
\cline { 2 - 8 } & Survey data & $7.8 \%$ & $8.4 \%$ & $15.6 \%$ & $43.6 \%$ & $18.4 \%$ & $6.2 \%$ \\
\hline \multirow{2}{*}{\begin{tabular}{l} 
Degree of cyber-threats \\
\hline
\end{tabular}} & Score & 0 & 1 & 2 & 3 & 4 & 5 \\
\cline { 2 - 8 }
\end{tabular}

Source: author construction based on materials of Electronic Dnipropetrovsk region 2020-2022 (2019) 
Table 2

\section{Level of electronic democracy}

\begin{tabular}{|c|c|c|c|c|c|c|c|}
\hline \multirow{2}{*}{ The level of use of information technologies by the population } & Score & 0 & 1 & 2 & 3 & 4 & 5 \\
\hline & Survey data & $0.6 \%$ & $6.1 \%$ & $13.4 \%$ & $43.6 \%$ & $29.1 \%$ & $7.3 \%$ \\
\hline \multirow{2}{*}{$\begin{array}{l}\text { The readiness of the authorities for electronic communication with } \\
\text { the public }\end{array}$} & & 0 & 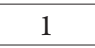 & 2 & 3 & 4 & 5 \\
\hline & Survey da & $2.8 \%$ & $10.1 \%$ & $1.2 \%$ & $6.9 \%$ & $0.1 \%$ & $8.9 \%$ \\
\hline \multirow{2}{*}{ The readiness of the population to get electronic services } & Score & 0 & 1 & 2 & 3 & 4 & 5 \\
\hline & urvey da & $1.1 \%$ & $7.8 \%$ & $16.2 \%$ & $46.9 \%$ & $1.8 \%$ & $6.1 \%$ \\
\hline \multirow{2}{*}{$\begin{array}{l}\text { Level of awareness and readiness of the population to use elements } \\
\text { of e-democracy and governmental information resources }\end{array}$} & $\mathrm{Scc}$ & 0 & 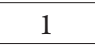 & & 3 & 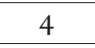 & 5 \\
\hline & Surve & $3.4 \%$ & $10.6 \%$ & $8.5 \%$ & $43.6 \%$ & $1.7 \%$ & $2.2 \%$ \\
\hline \multirow{2}{*}{$\begin{array}{l}\text { Level of use of the Internet and telecommunications by the public } \\
\text { to interact with the authorities and get public services }\end{array}$} & $\mathrm{Sc}$ & 0 & 1 & 2 & 3 & 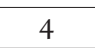 & 5 \\
\hline & urve & $0.6 \%$ & $10.1 \%$ & $4.0 \%$ & $43.0 \%$ & $19.0 \%$ & $3.4 \%$ \\
\hline \multirow{2}{*}{$\begin{array}{l}\text { Level of use of information technologies by public authorities for } \\
\text { public consultations }\end{array}$} & Sc & 0 & 1 & 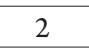 & 3 & 4 & 5 \\
\hline & urve & $3.9 \%$ & $11.7 \%$ & $25.7 \%$ & $35.2 \%$ & $17.9 \%$ & $5.6 \%$ \\
\hline \multirow{2}{*}{$\begin{array}{l}\text { Level of access to public information, transparency and accessibility } \\
\text { of information on the activities of public authorities }\end{array}$} & $\mathrm{Scc}$ & 0 & 1 & 2 & 3 & 4 & 5 \\
\hline & Surve & $1.1 \%$ & $11.2 \%$ & $16.2 \%$ & $33.0 \%$ & $29.1 \%$ & $9.5 \%$ \\
\hline \multirow{2}{*}{ Need for citizens' training on how to use the e-democracy tools } & & 0 & 1 & 2 & 3 & 4 & 5 \\
\hline & Surve & $0.0 \%$ & $1.7 \%$ & $1.1 \%$ & $15.6 \%$ & $22.9 \%$ & $58.7 \%$ \\
\hline \multirow{2}{*}{$\begin{array}{l}\text { Need for school training for young people on the use of the } \\
\text { e-democracy tools }\end{array}$} & & 0 & 1 & 2 & 3 & 4 & 5 \\
\hline & Survey dat & $0.6 \%$ & $0.0 \%$ & $2.8 \%$ & $7.3 \%$ & $14.5 \%$ & $74.9 \%$ \\
\hline \multirow{2}{*}{ Quality of public budget use (budget of participation) } & Score & 0 & 1 & 2 & 3 & 4 & 5 \\
\hline & Survey data & $7.8 \%$ & $11.2 \%$ & $16.2 \%$ & $40.8 \%$ & $17.3 \%$ & $6.7 \%$ \\
\hline
\end{tabular}

Source: author construction based on materials of Electronic Dnipropetrovsk region 2020-2022 (2019)

Table 3

Level of electronic governance development

\begin{tabular}{|l|c|c|c|c|c|c|c|}
\hline \multirow{2}{*}{ Level of e-government development in general } & Score & 0 & 1 & 2 & 3 & 4 & 5 \\
\cline { 2 - 7 } & Survey data & $2.2 \%$ & $6.1 \%$ & $19.0 \%$ & $43.0 \%$ & $26.3 \%$ & $3.4 \%$ \\
\hline \multirow{2}{*}{ Quality of the site of the authority } & Score & 0 & 1 & 2 & 3 & 4 & 5 \\
\cline { 2 - 7 } & Survey data & $2.8 \%$ & $3.4 \%$ & $10.1 \%$ & $30.2 \%$ & $39.1 \%$ & $14.5 \%$ \\
\hline \multirow{2}{*}{ Quality of provision of electronic administrative services } & Score & 0 & 1 & 2 & 3 & 4 & 5 \\
\cline { 2 - 7 } & Survey data & $5.0 \%$ & $6.1 \%$ & $15.1 \%$ & $35.2 \%$ & $30.7 \%$ & $7.8 \%$ \\
\hline $\begin{array}{l}\text { Level of use of electronic document flow (including } \\
\text { electronic signature) }\end{array}$ & Score & 0 & 1 & 2 & 3 & 4 & 5 \\
\hline \multirow{2}{*}{ Quality of e-procurement system } & Survey data & $2.2 \%$ & $11.2 \%$ & $15.6 \%$ & $36.3 \%$ & $25.7 \%$ & $8.9 \%$ \\
\hline
\end{tabular}

Source: author construction based on materials of Electronic Dnipropetrovsk region 2020-2022 (2019)

\section{Conclusions}

The peculiarities of country's digital society development in one of the industrialized regions of Ukraine have been determined on the example of research of territorial communities' electronic readiness.

Experts from three sectors of society authority, business, civil society - took part in the research. The expert survey was conducted using the Delphi method. The roadmap of the further development of information society in the region was presented in the form of Dnipropetrovsk region's informatization program «Electronic Dnipropetrovsk region 2020-2022».

The results of the research showed important problems and directions for further work on the development of digital economy and digital society in the region, such as:

- the level of access to the high-speed Internet in rural areas is far behind urban indices. The situation can be characterized as digital inequality, which leads to a restriction of population's access to e-services and is an obstacle to the development of the e-government in the local government. Experts see the solution to the issue in the dissemination of $4 \mathrm{G}$ mobile network access technologies through public-private partnerships;

- along with the great desire of population to develop the e-democracy, there is a problem of improper work of relevant digital resources. Another actual problem is the lack of necessary 
knowledge and skills among the representatives of the civil society and population in general;

- e-Government is developing actively in terms of technology and software, but its efficiency is still very low. By experts' opinion, it is caused by the low level of digital competencies of public officials and this requires special training programs and retraining of employees of public administration bodies.

\section{References:}

Baklanova, O., Petrova, M., \& Koval, V. (2020). Institutional Transmission in Economic Development. Ikonomicheski Izsledvania, vol. 29(1), pp. 68-91.

Dnipropetrovsk Region Council (2019). Available at: https://oblrada.dp.gov.ua/rishennia/sklikannia-7/ xviii-sesiya (in Ukrainian)

Dutton, W. H. (2003). Information Society. Encyclopedia of International Media and Communications.

E-Government Development Index (2018). UN E-Government Survey 2018. Available at: https://publicadministration.un.org/egovkb/en-us/Reports/UN-E-Government-Survey-2018

Electronic Dnipropetrovsk region 2020-2022 (2019). Available at: https://rpi2020-22.dp.gov.ua/storage/ app/sites/70/dridu/result\%20ex.pdf (in Ukrainian)

E-Participation Index (2018). UN E-Government Survey 2018. Available at: https://publicadministration.un.org/ egovkb/en-us/About/Overview/E-Participation-Index

Etscheid, J. (2019) Artificial Intelligence in Public Administration. Springer, Cham, vol. 11685, 248-261. Floridi, L. (2014). The Fourth Revolution: How the Infosphere is Reshaping Human Reality. Oxford University Press.

ICT development index (2017). Measuring the Information Society Report 2017. Available at: https://www.itu.int/en/ITUD/Statistics/Documents/publications/misr2017/MISR2017_Volume1.pdf Eurostat (2018). Individuals frequently using the internet. Available at: https://ec.europa.eu/eurostat/ $\mathrm{tgm} / \mathrm{table}$. do? tab $=$ table \&plugin $=1$ \&language $=$ en $\&$ pcode $=$ tin00092

Factum Group Ukraine (2019). Internet penetration in Ukraine. Available at: https://inau.ua/sites/ default/files/file/1910/dani_ustanovchyh_doslidzhen_iii_kvartal_2019_roku.pdf(in Ukrainian)

Koval, V., Zamlynskyi, V., \& Kolomiiets, O. (2018). Transformation of integration processes and management by development of the electronic services market. Structural transformation of the national economy in the context of Euro-regional cooperation. Warsaw: BMT Eridia Sp. z o.o., pp. 7-23.

Kvitka, S. (2020). Digital transformations as a modern trend of the periodic cycle of society development. Zbirnyk naukovykh prats Natsionalnoi akademii derzhavnoho upravlinnia pry Prezydentovi Ukraiiny Collection of scientific works of the National Academy of Public Administration under the President of Ukraine, SI, 131-134. doi: 10.36.030/2664-3618-2020-si-131-134 (in Ukrainian)

Kvitka, S., Borodin, E., Koval, V., Yemelyanov, V., \& Ivashova, L. (2019). Innovative mechanisms of the cross-sectoral interaction between business and public authorities in conditions of information society's transformation. Dilemas contemporaneos-educacion politica y valores, vol. 7 (SI), p. 133.

Kvitka, S., Novichenko, N., Husarevych, N., Piskokha, N., Bardakh, O., \& Demoshenko, G. (2020). Prospective directions of digital transformation of public governance. Public administration aspects, vol. 8(4), pp. 129-146. doi: 10.15421/152087

Mergel, I., Edelmann, N., \& Haug, N. (2019). Defining digital transformation: Results from expert interviews. Government Information Quarterly, vol. 36(4), p. 101385.

Tomi Dufva, T., \& Dufva, M. (2019). Grasping the future of the digital society. Futures, vol. 107, pp. 17-28.

UN E-Government Survey 2018. Available at: https://publicadministration.un.org/egovkb/en-us/ Reports/UN-E-Government-Survey-2018

Yankovyi, O., Goncharov, Yu., Koval, V., \& Lositska, T. (2019). Optimization of the capital-labor ratio on the basis of production functions in the economic model of production. Naukovyi Visnyk Natsionalnoho Hirnychoho Universytetu, vol. 4, pp. 134-140. 